\title{
RLUIPA, Distress, and Damages
}

\author{
Jennifer D. Larson $\dagger$
}

\begin{abstract}
$[P]$ risoners do not lose their right to practice their religion when the prison gate closes behind them.'
\end{abstract}

The common impression that a prisoner under sentence is pretty much at the arbitrary disposal of his keeper is not only exceedingly erroneous, but it is one that leads to many abuses.

Do prisoners have a right without a remedy? ${ }^{3}$ The Religious Land Use and Institutionalized Persons Act of $2000^{4}$ (RLUIPA or "the Act") provides that "[n]o government shall impose a substantial burden on the religious exercise of a person" confined in a prison. ${ }^{5}$ The Act further provides that a prisoner bringing a cause of action under RLUIPA may "obtain appropriate relief." But the Prison Litigation Reform Act of $1995^{7}$ (PLRA) bars claims for damages for mental and emotional distress without physical injury. Because violations of the right to freely exercise one's religion seldom cause physical injury, it is not clear whether or when prisoners suing under RLUIPA may recover compensatory damages when their statutory rights are violated. This Comment examines the apparent conflict between RLUIPA and PLRA.

The issue addressed here is the result of three developments. First, in 1990 the Supreme Court decided Employment Division $v$ Smith, ${ }^{8}$ which made it more difficult for individuals (including prisoners) to establish a violation of First Amendment rights in the particu-

+ BA 2004, University of Illinois at Chicago; JD Candidate 2008, The University of Chicago.

1 Moskowitz v Wilkinson, 432 F Supp 947, 948 (D Conn 1977), citing Cruz v Beto, 405 US 319 (1972).

2 Ho Ah Kow v Nunan, 12 F Cases 252, 254 n 2 (Cir Ct Cal 1879), quoting Thomas M. Cooley, Recent American Decisions: Ho Ah Kow v. Matthew Nunan, 18 Am L Reg 676,685-68 (1879).

3 "[T]he value of a right is a function of the consequences that will be brought to bear when the right is violated." Daryl J. Levinson, Rights Essentialism and Remedial Equilibration, 99 Colum L Rev 857, 904 (1999) (discussing rights and remedies as two parts of a whole). The Supreme Court and Levinson may not quite agree on this idea, but Levinson's article is an interesting and reasoned discussion of the relationship between rights and remedies.

4 Pub L No 106-274, 114 Stat 803 , codified at 42 USC $\$ 2000 \mathrm{cc}(2000)$.

542 USC $\$ 2000 \mathrm{cc}-1$ (a).

642 USC $\$ 2000 \mathrm{cc}-2(\mathrm{a})$.

7 Pub L No 104-134, 110 Stat 1321 (1996), codified in relevant part at 42 USC $\$$ 1997a-1997h (2000)

8494 US 872 (1990). 
lar context of "incidental impact" claims. Second, in 1995, for reasons unrelated to Smith, Congress enacted PLRA, which required physical injury for prisoner claims of mental and emotional distress. Third, in 2000 , Congress enacted RLUIPA in an effort to reverse by statute the effect of Smith on prisoners.

Because RLUIPA was intended to reinstate pre-Smith rights and remedies for prisoners, the pre-Smith framework for assessing damages for constitutional violations provides a useful baseline for assessing damages for violations of RLUIPA. A pair of Supreme Court decisions in 1978 and 1986 established the framework for awarding damages for constitutional torts, including violations of the First Amendment. Those decisions do not require physical harm for the recovery of compensatory damages.

This Comment argues that PLRA should not be construed to require physical harm as a predicate for the recovery of full compensatory damages under RLUIPA. Moreover, even if PLRA does limit the recovery of damages for mental and emotional distress under RLUIPA in the absence of physical harm, it does not bar the recovery of compensatory damages under RLUIPA for the loss of the free exercise rights that are protected by the statute.

\section{COMMON LAW OF COMPENSATION}

Two key Supreme Court cases govern how courts evaluate nonphysical injuries resulting from the deprivation of rights. Examining them together provides a summary of the common law of damages for constitutional torts. First, the decision in Carey v Piphus held that claims for constitutional torts are governed by traditional tort law. Then Memphis Community School District $v$ Stachura ${ }^{11}$ clarified that damages cannot be awarded for the abstract value of a right. ${ }^{12}$ Finally, traditional tort law provides alternatives to compensatory damages. Injunctions and nominal or punitive damages are appropriate alternatives under certain circumstances.

\section{A. Carey and Constitutional Torts}

Claims for constitutional torts can be brought under $\S 1$ of the Civil Rights Act of $1871 .{ }^{13}$ Examining the legislative history of $\S 1983$, the Court in Carey found that the section "was intended to [create] a

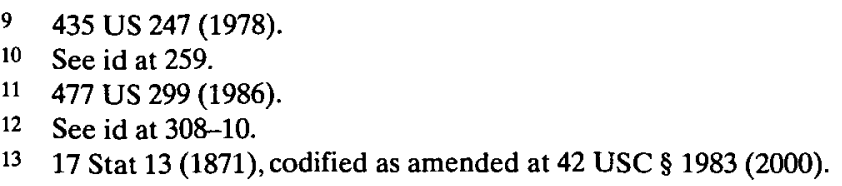


species of tort liability" for violations of constitutional rights. ${ }^{14}$ Such claims, the Supreme Court has held, are governed by the compensation principle of Anglo-American tort law.

Compensatory damages are designed to provide recompense for injuries, including those caused by the deprivation or violation of rights. ${ }^{16}$ Judges have considerable experience with private tort claims, and that experience allows them to make "the types of judgment concerning causation and magnitude of injury necessary to accord meaningful compensation for invasion of [constitutional] rights." common law rule may not provide "a complete solution to the damages issue." ${ }^{\prime 18}$ Constitutional rights and tort law protect generally parallel sets of interests, but when their protections diverge the "purpose of $\S 1983$ would be defeated if injuries caused by the deprivation of constitutional rights went uncompensated simply because the common law does not recognize an analogous cause of action." Judges must tailor compensation "for injuries caused by the deprivation of constitutional rights" according to the particular interests being protected. ${ }^{20}$

In Carey, the issue revolved around claims that a violation of due process resulted in mental and emotional distress. The Supreme Court found that if the denial of due process itself caused mental or emotional distress, it would not be difficult to produce evidence of its cause: "Distress is a personal injury familiar to the law, customarily proved by showing the nature and circumstances of the wrong and its effect on the plaintiff." "21 Compensatory damages for mental and emotional distress require "proof that such an injury was actually caused." If proof is provided, compensatory damages are allowed under $\S 1983$.

14435 US at 253 (explaining the function of $\$ 1983$ ) (alteration in original) (quotation marks omitted).

15 See id at 254-55 (discussing the compensation principle as reflected in $\$ 1983$ damages).

16 See id at 255-57 (noting that there were many lawyers in Congress in 1871 who would have been familiar with this basic concept of tort law).

17 Id at 259 (alteration in original), quoting Bivens $v$ Six Unknown Agents of Federal Bureau of Narcotics, 403 US 388, 409 (1971) (Harlan concurring).

18 Carey, 435 US at 258.

19 Id.

20 Id at 259.

21 Id at 263-64 ("[W]e foresee no particular difficulty in producing evidence that mental and emotional distress actually was caused by the denial of procedural due process itself."). The denial of a prisoner's right to freely exercise his religion is especially likely to cause mental and emotional distress, regardless of what other loss accompanies the deprivation. Not every loss, however, is accompanied by distress. See, for example, Kerman v City of New York, 374 F3d 93, 124 (2d Cir 2004) (finding that "the jury could have been persuaded that Kerman suffered no more than minimal psychic or emotional damage" from his false imprisonment). Kerman was, according to testimony, "witty" during his experience. Id.

22 Carey, 435 US at 264.

23 Id. 
The Court in Carey used defamation as an example of a tort "virtually certain to cause serious injury ... [that] is extremely difficult to prove." ${ }^{24}$ Like defamation, infringing a person's right to freely exercise his religion is "virtually certain to cause serious injury," although the injury would be to the person's state of mind rather than his reputation. Furthermore, the resulting damage might be impossible to prove the same way damages from conventional torts are proved. For instance, deprivation of worship services for several months may be a serious, though not physical, injury. ${ }^{25}$ In a similar situation, one court found that although it is difficult "to put a monetary value on the deprivation of an opportunity to practice one's religion ... the court believes that $\$ 50$ will adequately compensate [the prisoner] for his injury.",

Thus, compensatory damages are available for injuries -including mental and emotional distress - caused by a violation of constitutional rights. The Court's reasoning was based on traditional tort principles instead of on specific provisions of $\S 1983$. The reasoning is independent of any particular statute. Therefore, where claims are brought under specific statutes granting a cause of action (such as RLUIPA) instead of under $\S 1983$, such damages should remain available.

\section{B. Stachura and Compensable Loss}

The Supreme Court returned to the subject of damages in Stachura, holding that compensatory damages must be related to the injury and are never to reflect the abstract value a judge or jury places on the violated right. ${ }^{27}$ Absent physical injury, presumed damages may be appropriate when they "roughly approximate the harm that the plaintiff suffered and thereby compensate for harms that may be impossible to measure." ${ }^{28}$ The Supreme Court iterated that "neither the likelihood of such injury nor the difficulty of proving it is so great as to justify awarding compensatory damages without proof that such

24 Id at 262-63 (explaining that while serious harm to one's reputation almost inevitably produces mental and emotional distress, not every minor departure from due process will do the same). Although defamation law did not provide a good analogy for due process violations, First Amendment claims may be a better fit. See Stachura, 477 US at 314 (Marshall concurring) (quoting Carey's proposition that what makes damages appropriate for the violation of one constitutional right will not necessarily apply to a different right).

25 See Meyer $v$ Teslik, 411 F Supp 2d 983, 989 (WD Wis 2006) (holding that missing just three services caused more than de minimis harm and did not preclude a claim under RLUIPA).

26 Vanscoy $v$ Hicks, 691 F Supp 1336, 1338 (MD Ala 1988) (awarding compensatory damages to a prisoner who had been denied access-once - to the prison chapel).

27 See 477 US at 310 . In his concurrence, Justice Marshall stressed that nevertheless, substantial damages could properly be awarded "simply upon a showing" of the deprivation of a right (to vote, in one instance) "without requiring any further demonstration of damages." Id at 314 (Marshall concurring) (emphasis added).

28 Id at 311 (majority). 
injury actually was caused." ${ }^{29}$ But damages do not depend on the abstract value of a right; Stachura states that they depend only on "a particular injury...that might be compensated through substantial money damages." harm that cannot easily be quantified" and are independent of the value of the right that was violated. ${ }^{31}$ It is the harm, not the abstract right, which is being given some monetary value.

Justice Marshall clarified that the violation of a constitutional right "may itself constitute a compensable injury wholly apart from any emotional distress, humiliation and personal indignity, emotional pain, embarrassment, fear, anxiety and anguish suffered." 32 He reiterated that the jury instructions at issue in Stachura failed because they invited speculation about the right's abstract value instead of the actual loss sustained. ${ }^{33}$ Understanding Stachura "to hold that deprivations of constitutional rights can never themselves constitute compensable injuries ... would defeat the purpose of $\S 1983$ by denying compensation for genuine injuries caused by the deprivation." ${ }^{34}$

Where the harm is, in essence, the loss of the right, the actual compensable injury is the inability to exercise the right rather than any distress flowing from the loss. ${ }^{35}$ The damages resulting from an injury, such as the denial of a single worship service, may be impossible to measure, as the Court in Stachura acknowledges, ${ }^{36}$ but are nonetheless compensable. Regardless of the injury, what $\S 1983$ requires is "proof of an affirmative causal connection between the actions taken by a defendant and the alleged constitutional deprivation."." Once such deprivation is shown, Carey says that there must be actual (though not necessarily physical) injury; Stachura says that where the injury is difficult to measure, courts may reach a rough approximation.

\section{Noncompensatory Damages}

For many years the only relief available to inmates was injunctive relief. Courts issued injunctions ordering prisons to provide appropri-

29 Carey, 435 US at 264.

30 Stachura, 477 US at $311 \mathrm{n} 14$.

31 Id.

32 Id at 313 (Marshall concurring) (quotation marks omitted).

33 See id at 315 .

34 Id at 316.

35 See id at 313 ("[T] $[$ he violation of a constitutional right, in proper cases, may itself constitute a compensable injury.").

36 See id at 311 (majority). See also Vanscoy, $691 \mathrm{~F}$ Supp at 1338 (acknowledging the difficulty of putting a monetary value on one missed opportunity to worship).

37 Presley $v$ Edwards, $2007 \mathrm{WL} 174153, * 8$ (MD Ala) (holding that the requisite causal connection was not present with regard to some of the defendants). 
ate food for prisoners with restricted religious diets, for example, or to stop imposing disciplinary sanctions on prisoners who for religious reasons refused to cut their beards. ${ }^{38}$ While injunctive relief is necessary and appropriate for correcting ongoing problems, it fails to provide a remedy where the harm is unlikely to be repeated. ${ }^{39}$

Sometimes, however, courts will award other forms of relief either in addition to or instead of compensatory damages. For example, "[n]ominal damages, of which $\$ 1$ is the norm, are an appropriate means of vindicating rights whose deprivation has not caused actual, provable injury." And so a court, convinced that a plaintiff suffered no harm and therefore deserved no compensation damages, may yet award nominal damages. By allowing nominal damages without proof of injury, "the law recognizes the importance to organized society that [absolute] rights be scrupulously observed." "41

Punitive damages for constitutional violations may be awarded even when compensatory damages are not available. Instead of physical harm, punitive damages require only "evil motive or intent, or ... reckless or callous indifference to the federally protected rights of others." ${ }^{43}$ Even when compensatory damages are not available, "society has an interest in deterring and punishing all intentional or reckless

38 See, for example, Kahane v Carlson, 527 F2d 492, 495-96 (2d Cir 1975) (holding that the prison was required to provide a kosher diet); Barnett $v$ Rodgers, 410 F2d 995, 1003 (DC Cir 1969) (reversing and remanding the district court's dismissal of a religion-based challenge to the prison's meal system, with instructions to evaluate the system's constitutionality); Gallahan $v$ Hollyfield, 516 F Supp 1004, 1006 (ED Va 1981) (enjoining prison officials from requiring a Cherokee Indian prisoner to cut his hair); Moskowitz $v$ Wilkinson, 432 F Supp 947, 951-52 (D Conn 1977) (holding that a rule prohibiting beards in prison was unconstitutional as applied and that imposing disciplinary sanctions for the inmate's refusal to comply with the policy was also unconstitutional). Another district court in the Fourth Circuit recently acknowledged Gallahan as binding precedent for a case brought under RLUIPA protesting a prison grooming policy. The policies were sufficiently different-unlike in Gallahan, the prisoner was not compelled to cut his hair, although he was punished for not doing so-that the court found the judgment of prison officials merited deference and denied injunctive relief. See Ragland v Angelone, 420 F Supp 2d 507, 521-22 (WD Va 2006) (supplemental opinion). See also note 126, describing the current circuit split over RLUIPA's effect on grooming policies.

39 See, for example, Geiger v Jowers, 404 F3d 371, 375 (5th Cir 2005) (refusing to grant injunctive relief because the plaintiff had not "shown or even alleged a likelihood of future harm"), citing City of Los Angeles v Lyons, 461 US 95 (1983).

40 Shidler v Moore, 446 F Supp 2d 942, 946 (ND Ind 2006) (emphasis added), quoting Kyle v Patterson, 196 F3d 695, 697 (7th Cir 1999).

41 Carey, 435 US at 266.

42 Smith $v$ Wade, 461 US 30, 52 (1983). When the threshold for punitive damages was lower than that for compensatory damage, courts could and did award punitive damages without the showing necessary for compensatory damages. Id at 53 .

43 Id at 56. 
invasions of the rights of others, even though it sometimes chooses not to impose any liability for lesser degrees of fault." ${ }^{44}$

Following Carey and Stachura, courts have a clear map for determining damages for the violation of a right. If an actual injury was suffered (even if the injury is restricted to the loss of the right), compensatory damages should be awarded (per Carey) even where harm is difficult to measure (per Stachura). If no actual injury was suffered, the court may proceed to determine the appropriateness of nominal or punitive damages or, if recurrence is likely, an injunction..$^{45}$ At least outside of the prison context, where there is a violation there is a remedy; where there is harm there is recompense.

\section{A DECADE AND MORE OF TURMOIL: FROM SMITH THROUGH RLUIPA}

As seen above, when constitutional rights are violated, compensatory damages should be available. But what happens when the Supreme Court makes it much more difficult to show a violation and Congress both enacts stronger statutory protections and attempts to limit damages? Such is the story of Smith and its impact, Congress's reaction to Smith, and how PLRA and its physical injury requirement entered and altered the picture.

\section{A. Neutral Laws of General Applicability}

Alfred Smith and Galen Black belonged to the Native American Church and used peyote for sacramental purposes. They were subsequently fired from their jobs at a private drug rehabilitation organization. ${ }^{46}$ Although they claimed that "their religious motivation for using peyote place[d] them beyond the reach of a criminal law that is not specifically directed at their religious practice," Oregon denied them unemployment benefits." The Supreme Court eventually held that "if prohibiting the exercise of religion ... is not the object of the [law] but merely the incidental effect of a generally applicable and otherwise valid provision, the First Amendment has not been offended."

Prior to Smith, the prevailing test for a violation of the First Amendment's Free Exercise Clause had been the compelling interest

44 Id at 54-55. See also id at $55 \mathrm{n} 21$ ("[A]fter Carey punitive damages may be the only significant remedy available in some $\S 1983$ actions where constitutional rights are maliciously violated but the victim cannot prove compensable injury.").

45 Geiger, 404 F3d at 375 (denying an injunction where there was no threat of future violations).

46 Smith, 494 US at 874.

47 Id at 878 .

48 Id. 
test, expressed in Sherbert $v$ Verner: ${ }^{49}$ "[A]ny incidental burden on the free exercise of ... religion may be justified by a compelling state interest in the regulation of a subject within the State's constitutional power to regulate." ${ }^{\text {so }}$ But in Smith, the Court held that "the right of free exercise [of religion] does not relieve an individual of the obligation to comply with a valid and neutral law of general applicability on the ground that the law proscribes (or prescribes) conduct that his religion prescribes (or proscribes).".

Smith "produced widespread disbelief and outrage." was that any law, so long as it was of general applicability, would be compliant with the Free Exercise Clause, regardless of the law's incidental impact on religious activities or beliefs. ${ }^{53}$ Congress moved quickly to reestablish by statute what it had thought was established by the Constitution; in 1993 it passed the Religious Freedom Restoration Act" (RFRA). This "Act [t]o protect the free exercise of religion" ss specifically states that its purpose is to overturn Smith and restore the balancing test of Sherbert. ${ }^{56}$ It requires the government to show that any law substantially burdening a person's exercise of religion must be both "in furtherance of a compelling governmental interest" and the "least restrictive means" of furthering that interest.

The Supreme Court limited RFRA in City of Boerne v Flores, which concluded that Congress had "exceeded the scope of its enforcement power under $\S 5$ of the Fourteenth Amendment." While RFRA still applied to the federal government, it no longer applied to state governments. ${ }^{60}$ Determined to protect the free exercise of relig-

49374 US 398 (1963).

50 Id at 403 (quotation marks and citations omitted) (finding a violation of the Free Exercise Clause when appellant was disqualified from receiving unemployment benefits because her religion forbade her from working on Saturday).

51 Smith, 494 US at 879 (quotation marks omitted).

52 Douglas Laycock, The Remnants of Free Exercise, 1990 S Ct Rev 1, 1.

53 See id at 12 (discussing how the state may burden "disfavored religions" with laws that are formally neutral, but have a different impact or lack exceptions).

54 Pub L No 103-141, 107 Stat 1488 (1993), codified in relevant part at 42 USC $\$ 2000$ bb et seq $(2000)$.

$55 \quad 107$ Stat at 1488.

5642 USC $\$ 2000 \mathrm{bb}(\mathrm{b})(1)$ (stating that the purpose of the statute is "to restore the compelling interest test as set forth in Sherbert v. Verner, 374 U.S. 398 (1963) ... and to guarantee its application in all cases where free exercise of religion is substantially burdened").

57 See 42 USC $\$ 2000 \mathrm{bb}-1(\mathrm{~b})$.

58521 US 507 (1997).

59 Id at 512.

60 See id at 532-36. RFRA is constitutional as applied to the federal government and continues to be the standard for federal prisons. Cases evaluating RLUIPA claims have often looked to RFRA cases for guidance. See, for example, Agrawal v Briley (Agrawal III), 2006 US Dist LEXIS 88697, *19-32 (ND IIl), citing Webman v Federal Bureau of Prisons, 441 F3d 1022 (DC Cir 2006). 
ion, Congress responded to Boerne by passing RLUIPA in 2000, and in 2005 the Supreme Court confirmed its constitutionality. ${ }^{61}$

Unlike the First Amendment or RFRA, RLUIPA was narrowly written to apply only to two types of cases: those involving either religious land use ${ }^{62}$ or the exercise of religion by incarcerated ${ }^{63}$ persons. The provisions on incarcerated persons declare that "[n]o government shall impose a substantial burden on the religious exercise of a person residing in or confined to an institution ... even if the burden results from a rule of general applicability," that the law furthers a compelling governmental interest and is the least restrictive means of furthering that interest. ${ }^{66}$ RLUIPA extends to every nonfederal penal institution in the country.

61 See Cutter v Wilkinson, 544 US 709, 714 (2005).

62 See 42 USC $\$ 2000 \mathrm{cc}(\mathrm{a})(1)$. The provisions on land use prohibit government from imposing land use regulations "in a manner that imposes a substantial burden on the religious exercise of a person, including a religious assembly or institution." Id.

63 RLUIPA applies to people in "state-run institutions-mental hospitals, prisons, and the like." Cutter, 544 US at 720 . As of this writing only one published case has been brought on behalf of a person in a mental institution. See In re L.A., 2006 Vt 118, 912 A2d 977. The patient refused medicine because it would interfere with his religious beliefs. The court had difficulty distinguishing sincere belief from delusion and held that consequences "must be real, and not imaginary or delusional." Id at 981.

64 RLUIPA applies when "the substantial burden [on free exercise] is imposed in a program or activity that receives Federal financial assistance," 42 USC $\$ 2000 \mathrm{cc}-1$ (b)(1), and when "the substantial burden affects, or removal of that substantial burden would affect, commerce with foreign nations, among the several States, or with Indian tribes," 42 USC $\$ 2000 \mathrm{cc}-1(\mathrm{~b})(2)$. The Supreme Court held that "RLUIPA's institutionalized-persons provision [is] compatible with the Establishment Clause because it alleviates exceptional government-created burdens on private religious exercise." Cutter, 544 US at 720. RLUIPA has been challenged under the Spending Clause provision as well, but without success. Every circuit court of appeals to rule on the issue has held that RLUIPA "fits comfortably within Congress' Spending Clause authority." Madison v Virginia, 474 F3d 118, 124 (4th Cir 2006). See also Cutter v Wilkinson, 423 F3d 579, 584-90 (6th Cir 2005) (finding that RLUIPA does not violate the Spending Clause); Benning $v$ Georgia, 391 F3d 1299, 1305-08 (11th Cir 2004) (same); Charles v Verhagen, 348 F3d 601, 606-10 (7th Cir 2003) (same); Mayweathers v Newland, 314 F3d 1062, 1066-70 (9th Cir 2002) (same).

6542 USC \$2000cc-1(a). Recently the Supreme Court declined to resolve a circuit split over the interpretation of "substantial burden." For a general discussion of the split and the particular case denied certiorari, see generally Scott Budzenski, Comment, Tug of War: The Supreme Court, Congress, and the Circuits - The Fifth Circuit's Input on the Struggle to Define a Prisoner's Right to Religious Freedom in Adkins v. Kaspar, 80 St John's L Rev 1335 (2006).

6642 USC $\$ 2000 \mathrm{cc}-1$ (a). Noting that the government exerts tremendous control over the exercise of religion in state-run institutions, the Court has admitted that "RLUIPA thus protects institutionalized persons who are unable freely to attend to their religious needs and are therefore dependent on the government's permission and accommodation for exercise of their religion." Cutter, 544 US at 721.

67 See notes 58-61 and accompanying text. The reach of the Spending Clause is enormous. Courts have held that the incarceration program bears the burden of showing that it does not receive federal funds, and even private companies are considered surrogates of the state and act under color of law. See Coronel v Walker, 2006 WL 2923152, *5-6 (ND Miss) (assessing defendant corporation's relationship with the State of Hawaii and noting that the defendant institution "should bear the burden of proving facts to establish any exemption from [RLUIPA's] terms"). 


\section{B. The Intervening Act: The Prison Litigation Reform Act}

In the late 1960 s the impetus for prison reform began to grow, due in part to prisoners bringing $\$ 1983$ claims. ${ }^{68}$ Prisons were recognized to be filthy, unhealthy, unfit for human habitation. ${ }^{69}$ But by the early 1990s public perception changed to the view that prisoners were overwhelming the court system with frivolous lawsuits. ${ }^{70}$ Congress acted to limit these suits by passing PLRA.

PLRA contains numerous reforms intended to make it harder for a prisoner to file any type of lawsuit." The key provision regarding RLUIPA damages is 42 USC $\$ 1997 \mathrm{e}(\mathrm{e})$, which restricts the damages available to prisoners: "No Federal civil action may be brought by a prisoner confined in a jail, prison, or other correctional facility, for mental and emotional injury suffered while in custody without a prior showing of physical injury." This "physical injury requirement" places a significant bar in the way of prisoners seeking to recover damages

The Commerce Clause too has wide application. For instance, many RLUIPA cases deal with diet claims. See note 121 and accompanying text. Food resources nearly always cross state lines at some point; likewise for religious paraphernalia. For an example of a case relying on food crossing state lines, see Katzenbach v McClung, 379 US 294, 298-305 (1964) (holding that Ollie's Barbecue was subject to the Civil Rights Act because it served food that "moved in commerce" and that such food was subject to regulation under the Commerce Clause). For a discussion of the idea that "if every effect on interstate commerce were enough to trigger federal authority, there would be nothing that Congress could not regulate," see David P. Currie, The Constitution in the Supreme Court: The Protection of Economic Interests, 1889-1910, 52 U Chi L Rev 324, 348 (1985). For a recent decision finding that the Commerce Clause provides an insufficient jurisdictional hook for allowing damages from officials in their private capacities, see Daker v Ferrero (Daker II), 475 F Supp 2d 1325, 1342-47 (ND Ga 2007). This case is discussed again in note 152.

68 See James E. Robertson, A Saving Construction: How to Read the Physical Injury Rule of the Prison Litigation Reform Act, 26 SIU L J 1, 19-20 (2001) (providing the case law background for § 1983 claims). After Monroe v Pape, 365 US 167 (1961), § 1983 claims for “tort-like harms" became eligible for damages. Robertson, 26 SIU L J at 19.

69 See, for example, Holt v Sarver, 309 F Supp 362, 373-81 (ED Ark 1970) (describing prison conditions and deeming them "cruel and unusual"). For a discussion of prison reform after 1960, see generally Jonathan A. Willens, Structure, Content and the Exigencies of War: American Prison Law after Twenty-Five Years 1962-1987, 37 Am U L Rev 41 (1987).

70 For a history of $\S 1983$ actions before PLRA's enactment and the impetus for the Act, see generally Allison Cohn, Comment, Can $\$ 1$ Buy Constitutionality?: The Effect of Nominal and Punitive Damages on the Prison Litigation Reform Act's Physical Injury Requirement, $8 \mathrm{U}$ Pa J Const L 299 (2006). Also see generally Corbett H. Williams, Note, Evisceration of the First Amendment: The Prison Litigation Reform Act and Interpretation of 42 U.S.C. \$ 1997e(e) in Prisoner First Amendment Claims, 39 Loyola LA L Rev 859 (2006) (describing a circuit split in interpreting PLRA either broadly to preclude all First Amendment claims for damages or more narrowly to allow some claims to proceed).

71 For a more complete discussion of the provisions of PLRA, see generally Peter Hobart, Comment, The Prison Litigation Reform Act: Striking the Balance between Law and Order, 44 Vill L Rev 981 (1999).

$72 \quad 42$ USC \& $1997 \mathrm{e}(\mathrm{e})$. 
for RLUIPA claims. Courts have struggled to reconcile PLRA with the need for "appropriate relief" for nonphysical injuries.

Part of the problem may lie in the fact that PLRA was intended to curb perceived abuses of the courts by prisoners. ${ }^{74}$ It was not intended to prevent prisoners from bringing meritorious suits. ${ }^{5}$ But when Congress passed RLUIPA five years later, it did not clearly define the meaning of "appropriate relief" and made no attempt to reconcile the apparent conflict between RLUIPA - enacted with the goal of preserving rights - and PLRA - enacted with the goal of limiting remedies.

\section{CONFLICTING STATUTES}

RLUIPA and PLRA have not enjoyed peaceful coexistence. The text and context of RLUIPA indicate numerous possible interpretations. The overlapping territory between RLUIPA and the First Amendment has led to varied results when courts interpret claims. Furthermore, PLRA poses a complication and even raises the specter of unconstitutionality. RLUIPA's language of "appropriate relief" is in direct tension with PLRA's physical injury requirement.

\section{A. RLUIPA}

Congress attempted to specify how courts should interpret RLUIPA: it is not to be construed to amend or repeal PLRA, ${ }^{76}$ but it is to be "construed in favor of a broad protection of religious exercise, to the maximum extent permitted by the terms of this [Act] and the Constitution." Should any government entity violate the Act, petitioners are entitled to "appropriate relief." " Courts have varied in how

73 See Part III.B.

74 See generally Ann H. Mathews, Note, The Inapplicability of the Prison Litigation Reform Act to Prisoner Claims of Excessive Force, 77 NYU L Rev 536 (2002).

PLRA is actually comprised of two separate provisions, each with a decidedly different emphasis and purpose. First, PLRA contains the STOP provisions, which limit the circumstances under which courts may enter injunctions against unconstitutional prison conditions such as overcrowding, and which ostensibly were intended to "get the federal courts out of the business of running jails." Id at 547-48. Second, PLRA contains provisions that establish new procedural requirements for prisoners' civil suits designed "to curtail abusive prisoner tort, civil rights, and conditions litigation." Id.

75 See Jennifer Winslow, Comment, The Prison Litigation Reform Act's Physical Injury Requirement Bars Meritorious Lawsuits: Was It Meant To?, 49 UCLA L Rev 1655, 1657 (2002) ("Proponents of the PLRA touted it as a way to clamp down on frivolous and malicious prisoner lawsuits, and promised that it was not designed to prevent inmates from pursuing meritorious claims.").

7642 USC $\$ 2000 \mathrm{cc}-2$ (e) ("Nothing in this chapter shall be construed to amend or repeal the Prison Litigation Reform Act of 1995.").

$77 \quad 42$ USC \& $2000 \mathrm{cc}-3(\mathrm{~g})$.

78 Thus, RLUIPA "does not preclude an award of relief ... unless such relief is not "appropriate."” Agrawal v Briley (Agrawal In), 2004 US Dist LEXIS 16997, *44 (ND III). Regardless of 
they construe RLUIPA's relief provision but they agree that, at a minimum, injunctions are appropriate relief. ${ }^{79}$ One federal court concluded that it was "unwilling to assume that Congress intended to incorporate into RLUIPA the judge-made limits of potential liability under $\S 1983$ if other principles of tort law casting a broader net might result in 'appropriate relief." "s0

While the First Amendment provides constitutional rights that can only be determined by the Supreme Court and abrogated by constitutional amendment, RLUIPA provides statutory rights that can be revoked by an Act of Congress. For this reason, the parallels are never exact. Nevertheless, RLUIPA protections are stronger: they protect any exercise of a sincerely held religious belief, but the First Amendment only protects "observation of a central religious belief or practice."

When they file suit, prisoners' pro se complaints are to be read broadly by the courts so as to include all appropriate claims. ${ }^{82}$ Smith wrought such changes in the standard for First Amendment claims that courts often dismiss them and substitute RLUIPA claims. ${ }^{83}$ Bring-

the manifold religions prisoners practice, complaints converge. Prisoners wish to exercise their religious beliefs in some way which may or may not be familiar to prison officials, and they are thwarted in this effort by prison policies or individual actors. Complaints regarding religious restrictions on food, grooming policies, services, and religious items of various kinds (paraphernalia) dominate the field of RLUIPA claims. For examples, see notes 121-26, 132.

79 See Madison v Virginia, 474 F3d 118, 130-31 (4th Cir 2006) ("[A]ppropriate relief ordinarily includes injunctive and declaratory relief.").

80 Agrawal II, 2004 US Dist LEXIS 16997 at *45. Subsequently, the court awarded $\$ 1$ in nominal damages and reserved punitive damages to be ascertained by a jury. Agrawal $v$ Briley (Agrawal III), 2006 US Dist LEXIS 88697, *66 (ND Ill). Another court, however, upheld an award of over $\$ 300,000$ to the plaintiff, including $\$ 15,000$ for mental or emotional damages. Siggers-El v Barlow, 433 F Supp 2d 811, 815-20 (ED Mich 2006).

81 Borzych v Frank, 2006 US Dist LEXIS 82289, *9 (WD Wis) (quotation marks omitted), citing Hernandez $v$ Commissioner of Internal Revenue Service, 490 US 680, 699 (1989).

82 Hughes $v$ Rowe, 449 US 5, 9 (1980) ("It is settled law that the allegations of such a complaint, 'however inartfully pleaded' are held 'to less stringent standards than formal pleadings drafted by lawyers."') (citation omitted). Because Smith changed the standard for what constitutes a First Amendment violation, see Part II.A, it is much more difficult for prisoners to state a colorable First Amendment claim.

83 See, for example, Pratt $v$ Corrections Corporation of America, 124 Fed Appx 465, 467 (8th Cir 2005) (remanding a case claiming First Amendment violations for consideration under RLUIPA); Fulbright v Evans, 2005 US Dist LEXIS 40240, *19 (WD Okla) (raising a RLUIPA claim sua sponte); Wolfe $v$ Ferguson, 2005 US Dist LEXIS 40978, *69-78 (WD Ark) (examining a claim under RLUIPA sua sponte). Courts are not consistent in construing First Amendment claims as either RFRA or RLUIPA claims. Compare Wesley $v$ Sniezek, 2007 US Dist LEXIS 15671, *4-5 (ND Ohio) (failing to find a claim for RLUIPA violation although the complaint implied that the plaintiff was Muslim); Wickner v Symmes, 2007 WL 426795, *3-10 (D Minn) (failing to construe the complaint to include an RLUIPA claim); McRoy v Cook County Department of Corrections, 366 F Supp 2d 662, 672-83 (ND Ill 2005) (failing to construe First Amendment claims as RLUIPA claims), with Parks-El v Fleming, 2007 US App LEXIS 534, *7 (4th Cir) (remanding for the district court to reconsider the plaintiff's "RLUIPA claim and, by extension, his free exercise claim"). 
ing a claim under RLUIPA instead of $\S 1983$ (for a First Amendment violation) makes a difference in what the prisoner must show to win $\mathrm{his}^{\mathrm{84}}$ suit. Once the prisoner wins, however, the court faces a dilemma: the conflict between RLUIPA's "appropriate relief" term and PLRA's prohibition on damages for distress unaccompanied by injury.

\section{B. PLRA § 1997e(e) Splinters the Circuits}

Congress used PLRA to curtail prisoner litigation by limiting "equitable remedies to those that are narrowly drawn, that extend[] no further than necessary to correct the violation of the federal right." "Section 1997e(e) states that "[n]o Federal civil action may be brought by a prisoner ... for mental or emotional injury suffered while in custody without a prior showing of physical injury.", The section's plain language construction has been universally rejected by the courts to avoid an unconstitutional result; if it were read to require a physical injury before a prisoner could bring any claim at all, prisoners would be barred from bringing claims for many due process violations, for example. The Department of Justice has instead taken the position that PLRA "leaves untouched claims for damages brought to vindicate a constitutional right or to punish for violation of that right.." ${ }^{87}$ At least three circuits have found that prisoners are entitled to nominal and punitive damages for violations of constitutional rights. ${ }^{88}$ Section $1997 \mathrm{e}(\mathrm{e})$ does not address these forms of damages. ${ }^{89}$

Decisions from the federal courts of appeals reflect uncertainty about applying PLRA to First Amendment claims. The Ninth Circuit suggested that courts are misstating the claims being brought because the plaintiff is not asserting a claim for "mental or emotional injury."

84 In over one hundred RLUIPA cases studied for this Comment, only one was brought by a female prisoner: Fayson $v$ Earle, 2006 US Dist LEXIS 81567 (D Del) (holding that the denial of halal meals for a Muslim inmate gives rise to an RLUIPA claim).

85 Levinson, 99 Colum $\mathrm{L} \mathrm{Rev}$ at 888 (cited in note 3) (alteration in original) (quotation marks omitted) (theorizing that there is a right-remedy relationship of "remedial substantiation, meaning just that the practical value of a right is determined by its associated remedies").

8642 USC $\$ 1997 \mathrm{e}(\mathrm{e})$.

87 Allah v Al-Hafeez, 226 F3d 247, 252 (3d Cir 2000) (citing a Department of Justice brief and argument, where the Department had intervened in the suit).

88 See id; Rowe v Shake, 196 F3d 778, 781-82 (7th Cir 1999); Canell v Lightner, 143 F3d 1210, 1213 (9th Cir 1998). But see Napier v Preslicka, 314 F3d 528, 534 (11th Cir 2002) (holding proper the dismissal of a suit alleging Fourth Amendment violations but no physical injury). Yet note the tension with Stachura: "[I]njury to a First Amendment-protected interest could itself constitute compensable injury wholly apart from any emotional distress[,] ... anxiety[,] and anguish suffered by plaintiffs." 477 US at 315 (Marshall concurring) (quotation marks omitted) (finding that a circuit court opinion correctly stated the law of damages for a constitutional tort).

89 See, for example, Allah, 226 F3d at 253 (holding that $\$ 1997$ e(e) does not bar nominal damages or punitive damages premised on the violation of a right). 
$\mathrm{He}$ is asserting a claim for a violation of his First Amendment rights. The deprivation of First Amendment rights entitles a plaintiff to judicial relief wholly aside from any physical injury he can show, or any mental or emotional injury he may have incurred. Therefore, $\S 1997 \mathrm{e}(\mathrm{e})$ does not apply to First Amendment claims regardless of the form of relief sought.

Another court" cited Stachura and explained even more clearly that "[w]here the harm that is constitutionally actionable is physical or emotional injury occasioned by a violation of rights, $\S 1997 \mathrm{e}(\mathrm{e})$ applies. In contrast, where the harm that is constitutionally actionable is the violation of intangible rights-regardless of actual physical or emotional injury - section 1997e(e) does not govern."

Such a construction of $\S 1997 \mathrm{e}$ (e) follows from a careful analysis of the statute's language: "A prisoner is barred from bringing into federal court an action 'for' emotional damages suffered while in custody, unaccompanied by physical injury. However, the constitutional violations of the type at issue here are not actions 'for' emotional distress." ${ }^{3 / 3}$ Certain rights, the right to free exercise of religion prime among them, are "amorphous" rights." They are not concerned with preventing specific harms, such as unreasonable searches and seizures, but rather with preserving certain areas of choice from "all official control." "Shaims are brought for the loss of the right-to vote, for example, or to worship-and any emotional harm flows from that loss the way it would flow from any physical injury. Mental or emotional distress is a symptom only, not a cause of action.

The Seventh Circuit has reached mixed decisions on the issue of damages for mental and emotional distress under PLRA. It held in Zehner $v$ Trigg ${ }^{96}$ that $\S 1997 \mathrm{e}(\mathrm{e})$ restricts damages available for constitutional violations because other remedies exist and, even if they did not, "the Constitution does not demand an individually effective rem-

90 Canell, 143 F3d at 1213 (emphasis added). Canell was brought before RLUIPA was enacted; the same claims would now be brought under RLUIPA either in addition to or instead of First Amendment claims. Canell's vitality was reaffirmed by Oliver v Keller, 289 F3d 623, 627 n 5 (9th Cir 2002) ("Nothing in our holding today disturbs our prior holding in Canell.") In Oliver, the court addressed an issue involving confinement and the Fourteenth Amendment, not religious freedom. Id at 626 .

91 Shaheed-Muhammad v Dipaolo, 138 F Supp 2d 99 (D Mass 2001).

92 Id at 107 (emphasis omitted) (declining to find that $\$ 1997 \mathrm{e}(\mathrm{e})$ prevents all recovery for emotional harm).

93 Id, citing Stachura, 477 US at 308 n 11.

94 Shaheed-Muhammad, 138 F Supp 2d at 108 (describing violations of abstract rights).

95 Id, citing West Virginia Board of Education v Barnette, 319 US 624, 642 (1943).

96133 F3d 459 (7th Cir 1997). Zehner was brought by prisoners who had been exposed to asbestos and were seeking damages for mental and emotional distress, but who had no physical injuries. Id at $\mathbf{4 6 0}$. 
edy for every constitutional violation." ${ }^{97}$ But in Rowe $v$ Shake, ${ }^{98}$ the court refined its position with regard to First Amendment claims, holding that "deprivation of First Amendment rights standing alone is a cognizable injury." "Therefore, no other injury need be alleged in order for the court to grant relief. ${ }^{100}$

The Third Circuit, however, found in Allah $v$ Al-Hafeez ${ }^{101}$ that mental or emotional distress itself was the harm forming the basis for any award of damages. ${ }^{102}$ It believed that the Stachura analysis of damages resulting from deprivation of rights applied solely to voting rights cases. ${ }^{103}$ Yet the Supreme Court's analysis in Stachura uses the history of compensation for voting rights as an example of how damages should be assessed when rights are violated. At no point does the Court limit its analysis or its holding to voting rights alone; in fact, Stachura itself was about claims for First and Fourteenth Amendment violations and was remanded because the jury instructions were erroneous - not because compensatory damages were unavailable. ${ }^{104}$

Contrary to the Third Circuit's holding in Allah, the Supreme Court views damages for violations of rights as being compensation for loss of the right and any subsequent injury. ${ }^{105}$ The Third Circuit skipped the actual harm (the loss). The Allah court looked only to the accompanying and identifiable symptom of distress as though it were the basis of the claim.

Where claims are unconnected to physical harm, "§ 1997e(e) would bar a prisoner's recovery of compensatory damages for mental and emotional injury. But if that same prisoner alleges some other type of nonphysical injury, the statute would not foreclose recovery, assuming that the damages sought were not 'for' any mental or emo-

97 Id at 462. Otherwise, the court thought, qualified immunity might often be unconstitutional. Id.

98196 F3d 778 (7th Cir 1999). Both Rowe and Owen v Lash, 682 F2d 648 (7th Cir 1982), were First Amendment cases relating to prisoners' freedom to correspond. Neither court distinguished one First Amendment right from another.

99 Rowe, 196 F3d at 781 (explaining that a prisoner is entitled to judicial relief even when the only injury is the violation of a First Amendment right).

100 Id at 781-82 ("Rowe does not allege that he suffered any additional injury as a consequence of his mail being delayed, nor must he.... A prisoner is entitled to judicial relief for a violation of his First Amendment rights aside from any physical, mental, or emotional injury he may have sustained.").

101226 F3d 247 (3d Cir 2000).

102 Id at 250. The plaintiff emphasized that the loss was of his First Amendment right.

103 Id at 251, citing Stachura, 477 US at $311 \mathrm{n} 14$.

104 See 477 US at 310,312 (holding that damages based on the abstract value of rights are not a permissible element of compensatory damages and that the erroneous instructions were not harmless).

105 See Part I.B. 
tional injuries suffered." ${ }^{106}$ Such reasoning illustrates the problem courts face: are claims for the right or for the distress of being deprived of it? While PLRA can reasonably be read to ban compensation damages for RLUIPA violations in the absence of physical injury, the better reading is that appropriate relief should be governed by the traditional damages rule, which requires actual-but not physicalinjury when constitutional rights are violated. By analogy to First Amendment $\S 1983$ claims, the traditional rule should extend to injuries caused by violations of RLUIPA statutory rights.

\section{Conflict}

The narrowest reading of $\S 1997 \mathrm{e}(\mathrm{e})$ is that prisoners are barred from bringing claims solely for mental and emotional distress; but when a claim is brought for some other injury, mental and emotional distress may also be claimed. A prisoner bringing suit under RLUIPA would have a claim for violation of statutory rights and, usually, some associated loss, such as access to services. Either the violation of the right or the associated loss may lead to mental and emotional distress, but almost never physical injury.

The typical absence of physical injury is the crux of the problem. If applied to constitutional or RLUIPA claims, § 1997e(e) "would effectively immunize officials from liability for severe constitutional [or statutory] violations, so long as no physical injury is established." prisoner who suffered some physical harm would be allowed to recover damages for accompanying mental and emotional distress, but a prisoner who suffered serious violations of his constitutional or statutory rights without any physical harm would be unable to collect any damages. ${ }^{108}$ When the right violated is RLUIPA's statutory right of free exercise of religion, such a result is deeply problematic. ${ }^{109}$

106 Calhoun v Detella, 319 F3d 936, 940 (7th Cir 2003) (citations omitted). The Seventh Circuit recognized its holding in Rowe, but held that absent physical injury for an Eighth Amendment violation only nominal and punitive damages were available. Id at 940-41.

107 Siggers- $E l, 433 \mathrm{~F}$ Supp $2 \mathrm{~d}$ at 816 (finding that " $\$ 1997 \mathrm{e}(\mathrm{e})$ is unconstitutional as applied").

108 See id. The physical injury must be more than de minimis, id; this conclusion seems to be the consensus across the circuits. See, for example, Harris v Garner, 190 F3d 1279, 1286 (11th Cir 1999) (holding that PLRA requires more than de minimis injury); Siglar v Hightower, 112 F3d 191, 193 (5th Cir 1997) (same); Young v Medden, 2006 US Dist LEXIS 6885, *54 (ED Pa) (same). The Siggers- $E l$ court also recites a hypothetical from the plaintiff's brief demonstrating that a sadistic prison guard could inflict psychological torture resulting in catastrophic emotional harm that would be noncompensable under $\S 1997$ e(e)'s physical injury requirement. See 433 F Supp $2 d$ at 816.

109 For additional views on the constitutional problems of PLRA, see generally Sharon I. Fiedler, Comment, Past Wrongs, Present Futility, and the Future of Prisoner Relief: A Reasonable Interpretation of "Available" in the Context of the PLRA, 33 UC Davis L Rev 713 (2000) (discussing the background of PLRA and the provisions of $\S 1997 \mathrm{e}(\mathrm{a}))$. 
If RLUIPA is to be construed in favor of broad protection, appropriate relief should match that available for constitutional torts. But if it is to be construed strictly according to PLRA, appropriate relief might be limited to, at most, punitive damages. RLUIPA's provisions thus seem to contradict each other.

When bringing First Amendment claims, "prisoners need not allege a physical injury to recover damages because the deprivation of the constitutional right is itself a cognizable injury, regardless of any resulting mental or emotional injury." would be that the deprivation of free exercise (as a statutory right) is a cognizable-and compensable-injury. If the injury is the deprivation itself, then compensation for that injury may, according to traditional tort law, include damages for mental and emotional distress. Courts have not yet reached this conclusion. ${ }^{11}$

In fact, what is emerging in RLUIPA cases is more confusion than consensus. Courts are divided over whether PLRA applies to RLUIPA or First Amendment claims ${ }^{112}$ and whether it allows nominal or punitive damages. ${ }^{13}$ No court has yet found that compensatory damages are available for RLUIPA claims unaccompanied by physical injury. ${ }^{14}$ At least one court has awarded substantial compensatory damages for a First Amendment claim, PLRA notwithstanding." Other courts have simply indicated uncertainty.

110 Calhoun, 319 F3d at 940 (emphases added).

111 As of this writing, few published opinions have awarded monetary damages under RLUIPA. See, for example, Perez v Frank, 2007 US Dist LEXIS 27441, *47-48 (WD Wis) (holding that compensatory damages are unavailable, awarding nominal damages of $\$ 9$, and sending the question of punitive damages to trial); Agrawal III, 2006 US Dist LEXIS 88697 at *65-66 (awarding $\$ 1$ in nominal damages, reserving punitive damages to be determined by a jury, and finding compensatory damages barred by $\$ 1997 \mathrm{e}(\mathrm{e}))$.

112 See generally Williams, 39 Loyola LA L Rev 859 (cited in note 70).

113 See, for example, Marsh v Granholm, 2006 WL 2439760, *1, 14 (WD Mich) (adopting the magistrate's opinion, which noted that individual liability for damages under RLUIPA is an unsettled issue); Daker v Ferrero (Daker D, 2006 US Dist LEXIS 94593, *24 (ND Ga) (same); Guru Nanak Sikh Society of Yuba City $v$ County of Sutter, 326 F Supp 2d 1140, 1162 (ED Cal 2003) (same).

114 Only a handful of RLUIPA claims have presented any sort of injury. See, for example, Boles $v$ Neet, 402 F Supp 2d 1237, 1245 (D Colo 2005) (finding that the plaintiff suffered an eye injury). See also cases cited in note 154 .

115 See Siggers-El, $433 \mathrm{~F}$ Supp $2 \mathrm{~d}$ at $815-17$ (awarding the plaintiff $\$ 15,000$ in compensatory damages). The court stated that "since First Amendment violations rarely, if ever, result in physical injuries, construction of the PLRA against recovery of damages would defeat congressional intent and render constitutional protections meaningless." Id at 816 . The record does not make clear the basis for the original claim. 


\section{RLUIPA AS APPLIED}

In the six years since RLUIPA was enacted, courts have been consistent in weeding out frivolous lawsuits. ${ }^{116}$ Otherwise, courts approach prisoner litigation in fitful fashion. As mentioned above, the preexisting circuit split over how PLRA applies to First Amendment cases has mapped directly onto RLUIPA cases. ${ }^{117}$ Additional circuit splits have developed over not just how RLUIPA affects details of specific policies, ${ }^{118}$ but over how to assess claims ${ }^{119}$ and what types of damages (if any) are available. ${ }^{120}$

Examining a few results in RLUIPA cases brings to light some of these concerns. In one area of RLUIPA there is wide agreement: courts are comfortable awarding injunctive and declaratory relief. Courts have also addressed the issues of monetary relief and sovereign immunity; the Fourth Circuit recently issued the first circuit court opinion on the subject. Finally, some courts have considered requests for nominal and punitive damages.

\section{A. Injunctions and Declaratory Relief}

Displaying sensitivity to plaintiffs' prayers for relief by issuing injunctions, for instance where an inmate requests a special diet to comply with religious restrictions, courts have extended pre-Smith protection for religious dietary needs. ${ }^{121}$ Courts have found that governments (including prisons and officials) impose substantial burdens on prisoners' exercise of religious beliefs, and that they do not use the least restrictive means of furthering compelling government interests. ${ }^{122}$

116 See, for example, Kretchmar v Beard, 2006 US Dist LEXIS 49530, *15-17 (ED Pa) (dismissing the suit for failure to state a claim - the prisoner desired hot instead of cold Kosher meals).

117 See note 112 and accompanying text.

118 See note 126 for a short discussion of a split on grooming policies.

119 In particular, courts have varied in how they evaluate "substantial burden"; how they evaluate the belief (as merely sincere, as central to the religion, or as part of the mainstream doctrine); and how much deference to give prison officials, which goes to the "least restrictive means" requirement. See note 83 for examples of these differing approaches to construing claims brought under the First Amendment as RLUIPA claims and vice versa.

120 The differences among courts on the various aspects of damages are noted below.

121 Cases holding that prisons must respect inmates' religious diet restrictions stretch back to before Smith. See, for example, French v Owens, 777 F2d 1250, 1255 (7th Cir 1985) (affirming the district court ruling requiring "safe, sanitary and nutritious food" for inmates); Ross $v$ Coughlin, 669 F Supp 1235, 1241 (SDNY 1987) (finding it well established that "prison authorities must accommodate the rights of prisoners to receive diets consistent with their religious beliefs"), citing Kahane v Carlson, 527 F2d 492, 495 (2d Cir 1975). Ross was a First Amendment case, evaluated under Turner $v$ Safley, 482 US 78, 89-91 (1987).

122 See, for example, Sample v Lappin, 424 F Supp 2d 187, 195 (DDC 2006) (allowing the RLUIPA claim for a prisoner who believed wine to be a necessary part of his religious diet); Fulbright $v$ Evans, 2005 US Dist LEXIS 40240, *46 (WD Okla) (finding reasons for refusal to provide inmate a kosher diet to be de minimis); Agrawal v Briley (Agrawal I), 2003 US Dist 
Likewise courts have granted some relief where inmates requested special services. ${ }^{123}$ Allowing prisoners a visit with clergy is an ancient custom, and this country has traditionally allowed prisoners access to chaplains. ${ }^{124}$ Prisoners bringing claims under RLUIPA, however, are often seeking more than mere access to a religious leader; hence, requests for certain types of religious services or permission for certain rites can raise serious security concerns. ${ }^{125}$

LEXIS 21365, *7-8 (ND IlI) (declaring that the defendants "were placing a 'substantial burden" on plaintiff's exercise of his religion by making him choose between religious observance and adequate nutrition"). See also Levitan v Ashcroft, 281 F3d 1313, 1319-20 (DC Cir 2002) (holding that First Amendment protection for religious beliefs does not require the beliefs to be "mandatory," where Catholic inmates had sued to be allowed Communion wine). But see Baranowski $v$ Hart, 486 F3d 112, 125 (5th Cir 2007) (affirming the district court's grant of summary judgment because the government's interest in controlling costs outweighed the plaintiff's interest in a kosher diet); Andreola $v$ Wisconsin, 211 Fed Appx 495, 498-99 (7th Cir 2006) (denying a RLUIPA charge where the prison provided an inmate with kosher meals, but refused to allow him to prepare his own food in the prison kitchen); Edelkind $v$ Neustrom, 2006 US Dist LEXIS 52407, *27-35 (WD La) (dismissing RLUIPA claims for a prisoner who was denied kosher meals while transitioning into the prison).

Prisoners may be required to meet prison officials half way: "Neither the Constitution nor Islam requires that [the plaintiff] receive Kool-Aid® or the same meals as other inmates." $M a l$ lory $v$ Winchester, 2006 US Dist LEXIS 90581, *6 (ND Ind) (dismissing RLUIPA claims). Yet when diet restrictions extend even to handling certain foods, prisons must still respect the prisoner's beliefs. See, for example, Williams v Bitner, 359 F Supp 2d 370, 372-73, 378 (MD Pa 2005) (holding that defendants were not entitled to qualified immunity on RLUIPA claims when they forced a Muslim prisoner to handle pork when working in the prison kitchen).

123 See, for example, Buchanan v Burbury, 2006 US Dist LEXIS 48244, *23-24 (ND Ohio) (issuing a preliminary injunction to a Sabbatarian who had been required to worship with Protestants). But see Baranowski, 486 F3d at 124-25 (holding that denial of services for Jewish inmates-when no rabbi or approved volunteer was present-did not place a substantial burden on their free exercise of religion); Price v Caruso, 451 F Supp 2d 889, 896-98 (ED Mich 2006) (denying injunction where the prisoner wanted to be transferred to another prison to have a quorum for services). See also McManus v Bass, 2006 US Dist LEXIS 24272, *28-29 (ED Va) (withholding judgment on the issue of injunctive relief for the plaintiff, who had been removed from the list for kosher meals).

124 Visiting prisoners was considered an important act of charity in early modern Europe. See Brian Pullan, Catholics, Protestants, and the Poor in Early Modern Europe, $35 \mathrm{~J}$ Interdiscipl Hist 441, 443-44 (2005). For an early American reference, see Commonwealth $v$ Drake, 15 Mass $161,161 \mathrm{n}$ (a) (1818) (referring to "the chaplain of the jail").

125 Of the RLUIPA claims studied for this Comment, those protesting denial of religious services are some of the most variable and difficult for prison officials to accommodate. Some prisoners merely seek permission to attend services more often, while others vehemently object to the type of religious services they are offered. See, for example, Bloch $v$ Samuels, 2006 US Dist LEXIS 53732, *20-23 (SD Tex) (denying claims under RLUIPA and RFRA to a plaintiff asking permission to go to daily Mass); Buchanan, 2006 US Dist LEXIS 48244 at *23-24 (finding a violation of RLUIPA and granting a preliminary injunction where a prison misclassified Sacred Name Sabbatarians as Protestant Christians and forced them to worship together). Security concerns are always paramount in a prison setting. See, for example, Salgado v Grams, 2006 US Dist LEXIS 86788, *2-3 (WD Wis) (finding it reasonable to prohibit an inmate from attending religious services when the Latin Kings gang had placed a hit on him); Marsh v Granholm, 2006 US Dist LEXIS 59203, *3 (WD Mich) (finding "serious safety concerns" where a convicted murderer requested to hold Wiccan ceremonies in private, outdoors: "[T] he mere fact of Plaintiff's incarceration is at odds with the ability to engage [in such] behavior"). But see $S$ mith $v$ 
RLUIPA claims requesting injunctions against restrictive grooming policies have met with mixed results. ${ }^{126}$ In Warsoldier $v$ Woodford, ${ }^{127}$ the court found that "the grooming policy constitutes a substantial burden on Warsoldier's religious practice," and that the prisoner faced irreparable injury if the court did not enjoin enforcement of the policy. ${ }^{128}$ Warsoldier was a Native American who believed that if he cut his hair he would not only lose his wisdom and strength, he would also lose the ability "to join his ancestors in the afterlife and that instead, the deceased members of his tribe will subject him to taunting and ridicule." ${ }^{129}$ The court found that the "policy forces Warsoldier to choose between following his religious beliefs and suffering continual punishment, and abandoning his religious beliefs to avoid

Beauclair, 2006 US Dist LEXIS 56561, *19-23 (D Idaho) (allowing a claim for injunctive relief to proceed where defendants did not adequately consider possible accommodation for a Cherokee Sacred Fire ritual).

126 The Ninth Circuit has held that a strict grooming policy violated RLUIPA, but the Eleventh has found otherwise. Compare Warsoldier $v$ Woodford, 418 F3d 989, 999-1001 (9th Cir 2005) (finding the government's arguments unconvincing in light of demonstrated alternatives), with Brunskill v Boyd, 141 Fed Appx 771, 776 (11th Cir 2005) (deciding without discussion that a grooming policy did not violate RLUIPA). Protests against grooming policies have been brought primarily by Muslim prisoners who wanted to grow beards, and Native Americans, Rastafarians, and Nazarites who, because of sincerely held religious beliefs, did not want to cut their hair. See, for example, Thunderhorse v Pierce, 418 F Supp 2d 875, 894-95 (ED Tex 2006).

Prisoners today no longer find courts as sympathetic as they once were. See, for example, $H o$ Ah Kow v Nunan, 12 F Cases 252, 253 (Cir Ct Cal 1879) ("The maltreatment consisted in having wantonly and maliciously cut off the queue of the plaintiff, a queue being worn by all Chinamen, and its deprivation being regarded by them as degrading and as entailing future suffering."). The court held, in conferring judgment on the plaintiff:

A treatment to which disgrace is attached, and which is not adopted as a means of security against the escape of the prisoner, but merely to aggravate the severity of his confinement, can only be regarded as a punishment additional to that fixed by the sentence. If adopted in consequence of the sentence it is punishment in addition to that imposed by the court; if adopted without regard to the sentence it is wanton cruelty.

Id at 254 (emphasis added). See also Moskowitz $v$ Wilkinson, 432 F Supp 947, 949-50 (D Conn 1977) (ruling that the "showing of a belief or practice deeply rooted in religious doctrine is sufficient to trigger the Government's obligation under the Constitution to justify its restriction as reasonably necessary in support of an important or substantial interest").

Grooming remains a contentious issue. See, for example, Thompson $v$ Scott, 2007 US Dist LEXIS 21742, *23-24 (SD Tex) (ordering trial to determine if a policy requiring hair to be cut to one-eighth inch was the least restrictive means available); State $v$ Whitaker, 2007 Ohio App LEXIS 781, *17-19 (vacating a sentence imposed when an inmate of a residential program refused to cut his hair for religious reasons, and the prisoner showed that the program did not consider less restrictive means of preserving security). For a further discussion of grooming policies in prisons, see generally Mara R. Schneider, Note, Splitting Hairs: Why Courts Uphold Prison Grooming Policies and Why They Should Not, 9 Mich J Race \& L 503 (2004) (arguing that grooming policies infringe the constitutional right to free exercise of religion).

127418 F3d 989 (9th Cir 2005).

128 See id at 1001.

129 Id at 992. 
such punishment." ${ }^{130}$ Unwilling to put Warsoldier to such a choice, the Ninth Circuit enjoined the policy as it applied to him. ${ }^{131}$

Requests for paraphernalia are especially difficult for courts to accommodate, because nearly anything can be turned into a weapon. ${ }^{132}$ Some prisons seem to be making a concerted effort to accommodate even unusual religions. ${ }^{133}$ Courts have occasionally denied injunctions for ongoing situations, either because no RLUIPA violation was found or because the issue had become moot when circumstances changed. ${ }^{134}$ One court denied an injunction because the defendant was a govern-

130 Id at 1001. After comparing the California Department of Corrections and Rehabilitation (CDC) with other prison systems-including the federal prison system - with less restrictive policies, it drew the conclusion that the " $\mathrm{CDC}$ has utterly failed to demonstrate that the disputed grooming policy is the least restrictive means necessary to ensure prison safety and security." Id at 999-1002. See also Watts v Director of Corrections, 2006 US Dist LEXIS 56193, *13-18 (ED Cal) (following Warsoldier, but holding that officials were entitled to qualified immunity); Von Staich $v$ California Department of Corrections, 2006 US Dist LEXIS 73110, *15-17 (ND Cal) (same). The CDC changed its grooming regulations in response to Warsoldier. See David v Giurbino, 2007 WL 925802, *2 (SD Cal) (discussing changes in grooming regulations resulting from RLUIPA).

131 See Warsoldier, 418 F3d at 1002. But see Hoevenaar v Lazaroff, 422 F3d 366, 371-72 (6th Cir 2005) (reversing the district court's injunction enjoining the prison from cutting a Native American inmate's hair). In a typical example of the uncertain state of RLUIPA jurisprudence, the Sixth Circuit did not employ the same "least restrictive means" test that the Ninth Circuit used. Compare id at 369-72, with Warsoldier, 418 F3d at 998-1001.

132 Cases involving clothing and religious items are plentiful. See, for example, Hammons $v$ Jones, 2006 US Dist LEXIS 7720, *11-13 (ND Okla) (holding that denying access to prayer oils imposed a substantial burden on the prisoner's exercise of religion); Boles $v$ Neet, 402 F Supp $2 \mathrm{~d}$ 1237,1246 (D Colo 2005) (allowing plaintiff to seek damages for injury suffered when the plaintiff was not allowed to wear a yarmulke when leaving the prison for eye surgery). See also Fayson $v$ Earle, 2006 US Dist LEXIS 81567, *3 (D Del) (noting that the plaintiff was allowed to wear her headscarf); Thunderhorse, $418 \mathrm{~F}$ Supp 2d at 891-92 (holding that the confiscation of a crystal from a Native American inmate did not violate RLUIPA).

Some requests are obviously dangerous but others are relatively benign. Compare Corey $v$ South Carolina Department of Corrections, 2007 WL 29024, *8-9 (D SC) (finding that the prison's strong interest in keeping a possible weapon out of the hands of a maximum security inmate justified denying his request for a rosary), with Benning v Georgia, 391 F3d 1299, 1313 (11th Cir 2004) (affirming that prisoner had an RLUIPA claim for being refused permission to wear a yarmulke).

Although the court in Corey applied an incorrect standard to the request, requiring the rosary to be necessary to the plaintiff's practice of religion rather than part of a sincerely held belief, see 2007 WL 29024 at $* 8$, the same result would probably have been reached under RLUIPA's standard. In spite of RLUIPA's language of compelling interest and least restrictive means, courts continue to show considerable deference to prison officials and the scope of deference shown to sincere belief in the prisoner, or expertise in security in prison officials, remains extremely uncertain.

133 See, for example, Smith $v$ Haley, 401 F Supp 2d 1240, 1243 (MD Ala 2005) (noting that prison officials changed their policy after suit was brought; they recognized Odinism as an official religion, allowed for a designated place of worship where the prisoner could "conduct his [rites]," allowed the prisoner to wear a necklace with a religious emblem-Thor's Hammer - and allowed him to light a candle).

134 See, for example, Price, 451 F Supp 2d at 900-01 (holding that the plaintiff's transfer to another facility had mooted his claims for injunctive and declaratory relief, but not his claims for compensatory damages); Haley, $401 \mathrm{~F}$ Supp $2 \mathrm{~d}$ at 1243 (finding that all but one of the plaintiff's claims became moot after the prison had changed its policies). 
ment actor, explaining: "[W]hen the defendant is not a private citizen but a government actor, there is a rebuttable presumption that the objectionable behavior will not recur." ${ }^{135}$

Plaintiffs also sometimes seek declaratory relief, which can be useful even after their claims have been rendered moot for the purposes of an injunction, because "a declaratory judgment as a predicate to a damages award can survive" even after claims for injunctive relief are dismissed. ${ }^{136}$ When prison officials change their policies, that change "does not moot plaintiff's claim for either declaratory or monetary relief." ${ }^{137}$

\section{B. Monetary Damages and Sovereign Immunity}

Two issues of immunity arise under RLUIPA: sovereign immunity for states and qualified immunity for officials. Sovereign immunity has concerned the courts because it was not entirely clear if, by accepting federal funds, states waived their Eleventh Amendment immunity from suit. ${ }^{138}$ Most initial cases under RLUIPA were dismissed on the grounds of qualified immunity, and thus preempted serious analysis of what damages are available. ${ }^{139}$ Courts are now trending toward finding that states waive immunity to suit, but not immunity to monetary damages. ${ }^{140}$ In other words, prisoners can sue governments but cannot claim monetary damages. Courts remain divided, however, over the questions of the availability of nominal and punitive damages as well.

135 Limbaugh $v$ Thompson, 2006 WL 2642388, *4 (MD Ala) (alteration in original) (quotation marks omitted) (holding that claims were mooted due to policy changes, and "because the defendants are government officials, the court may confidently presume that the defendants will continue to allow the plaintiffs and other Native American inmates in the general population to participate in sweat lodge ceremonies"). But see Acoolla $v$ Angelone, 2006 US Dist LEXIS $62574,{ }^{*} 37$ (WD Va) (noting the court's deep concern about the possibility of prison officials continuing to impose punishments despite a court order, and specifically giving plaintiff leave to reopen the case if he were ever disciplined again with the same issue).

136 Shidler $v$ Moore, 446 F Supp 2d 942, 947 (ND Ind 2006) (quotation marks omitted).

137 Id (quotation marks omitted).

138 The Eleventh Amendment grants states immunity from lawsuits filed against them by citizens of another state. The Supreme Court has recognized that immunity also applies to nonconsensual suits against a state filed by its own citizens. See Hans v Louisiana, 134 US 1, 14-15 (1890); Blatchford $v$ Native Village of Noatak and Circle Village, 501 US 775, 779 (1991); Alden v Maine, 521 US 706, 712-13 (1999).

139 See, for example, Bilal v Lehman, 2006 US Dist LEXIS 89430, *14-15 (WD Wash). Much, of course, turns on what a court determines a reasonable person would have known. In fact, "[t]he qualified immunity standard gives ample room for mistaken judgments by protecting all but the plainly incompetent or those who knowingly violate the law." Id at * 15 , quoting $\mathrm{Mal}$ ley $v$ Briggs, 475 US 335, 341 (1986). (ND Ill).

140 See generally, for example, Agrawal v Briley (Agrawal III), 2006 US Dist LEXIS 88697 
The Fourth Circuit concluded in Madison v Virginia ${ }^{141}$ that states do not waive their immunity to money damages under RLUIPA by accepting federal funds for state prisons. ${ }^{142}$ Furthermore, even if the state were amenable to suit, such amenability does not automatically provide for monetary damages. ${ }^{143}$ The court stated, "We conclude that RLUIPA's 'appropriate relief against a government' language falls short of the unequivocal textual expression necessary to waive State immunity from suits for damages." strued in favor of immunity," ${ }^{145}$ monetary damages from defendants sued in their official capacities "are unavailable under RLUIPA." ${ }^{146}$ No money damages are available from individuals in their official capacities because no money damages are available from the state. ${ }^{14}$ Essentially, then, "the suit against the defendants in their official capacities is barred by the Eleventh Amendment." ${ }^{18}$

Already immune in their official capacities, government officials may also be granted qualified immunity. "The doctrine of qualified immunity protects state officials from personal liability for on-the-job conduct so long as the conduct is objectively reasonable and does not violate an inmate's clearly-established federal constitutional and statutory rights." ${ }^{149}$ As mentioned above, most early RLUIPA suits

141474 F3d 118 (4th Cir 2006).

142 See id at 122-23. The Madison court held that states did not waive their Eleventh Amendment sovereign immunity for RLUIPA cases because Congress did not "expressly and unequivocally" condition the use of federal prison funds on a state's waiver of immunity against money damages. Id at 130. See also Agrawal III, 2006 US Dist LEXIS 88697 at *20-21, citing Board of Trustees of University of Alabama v Garrett, 531 US 356, 364 (2001) and Cherry v University of Wisconsin System Board of Regents, 265 F3d 541, 554 (7th Cir 2001). Congress did not make funding for prisons expressly conditional on waiving immunity to claims under RLUIPA; and because RLUIPA lacks language such as "a State shall not be immune," the fact that RLUIPA "creates a cause of action against the states and applies where a state accepts federal funding" does not mean the state waives immunity by accepting funding. Agrawal III, 2006 US Dist LEXIS 88697 at *25-26. RLUIPA contains one provision for when it applies, and another creating a cause of action. The court explained that "nothing in RLUIPA explicitly ties the two provisions together ... or explicitly declares that states cannot assert sovereign immunity .... Indeed, RLUIPA never mentions immunity at all." Id.

143 Madison, 474 F3d at 131.

144 Id.

145 Id, citing United States v Nordic Village, Inc, 503 US 30, 34 (1992).

146 Agrawal III, 2006 US Dist LEXIS 88697 at *32. See also James v Price, 2005 WL 483443, *2 (ND Tex) (finding that Texas had not waived its sovereign immunity to claims for monetary relief).

147 See James, 2005 WL 483443 at *2 (reasoning that a "suit against an official in his official capacity is actually a suit against the state"). See also Limbaugh, 2006 WL 2642388 at *6 (holding, parallel to Agrawal $I I I$, that Alabama had not expressly waived its immunity to claims for monetary damages); Blount $v$ Johnson, 2006 US Dist LEXIS 90979, *7 n 2 (WD Va) (holding without explanation that an officer was not liable in his official capacity).

148 James, 2005 WL 483443 at $* 2$.

149 Bilal, 2006 US Dist LEXIS 89430 at*14-15 (WD Wash), citing Harlow v Fitzgerald, 457 US 800, 818 (1982). 
never reached the issue of damages because they were dismissed upon a finding of qualified immunity for the officials.

Courts disagree about whether or not officials are liable in their individual capacities. ${ }^{151}$ If monetary damages are unavailable from the state, a prisoner's only chance for compensatory damages is to sue an actor in his individual capacity. Because RLUIPA's language in 42 USC $\$ 2000 \mathrm{cc}-5(4)$ tracks closely with that in $\$ 1983$, courts have reasoned that Congress must have meant to include officials in their

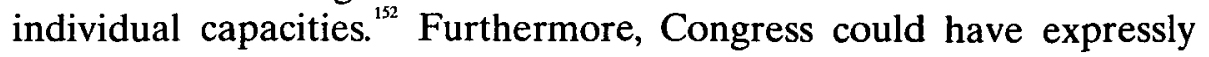
limited relief to equitable or declaratory relief, but did not. If RLUIPA had been meant to exclude certain forms of relief, it could easily have done so; the fact that it did not may mean that monetary damages are available. ${ }^{153}$ Nevertheless, the availability of monetary

150 See, for example, Morris-El v Menei, $2006 \mathrm{WL} 1455592$, *6 (WD Pa) (finding that the facts predated RLUIPA, but that official conduct would have been reasonable under RLUIPA and thus qualified immunity barred any damages); Haley, 401 F Supp 2d at 1246-50 (holding that the defendants were qualifiedly immune from damages despite violating RLUIPA by denying the prisoner a crystal); Charles, $220 \mathrm{~F}$ Supp 2d at 953-54 (holding that prison officials violated RLUIPA by denying the plaintiff prayer oils but are protected against damages by qualified immunity).

151 See Lovelace $v$ Lee, 472 F3d 174, 196 n 7 (4th Cir 2006) (leaving open the question of damages for claims against officials in their personal capacity and collecting district court cases to illustrate a split in authority on the question).

152 See, for example, Daker v Ferrero (Daker I), 2006 US Dist LEXIS 94593, *30-31 (ND $\mathrm{Ga}$ ) (evaluating the possibility of compensatory damages from individuals in their personal capacity). But see Daker v Ferrero (Daker II), 475 F Supp 2d 1325, 1333-34, 1346 (ND Ga 2007) (holding that RLUIPA does not authorize suit against prison officials in their individual capacities). Daker $I I$ is the first published RLUIPA opinion to analyze the constitutionality of suits against officials in their individual capacities by specifically taking into account that the jurisdictional hooks are the Spending and Commerce Clauses.

The opinion is thorough, but the analysis under the Commerce Clause may be problematic because it relies heavily on a Supreme Court opinion of uncertain implications, United States $v$ Morrison, 529 US 598 (2000). The Daker II court concluded that allowing damages against prison officials in their individual capacities "would unmoor RLUIPA from its firm grounding in the Spending Clause ... and engender debate about whether it regulates localized, non-economic conduct that does not substantially affect interstate commerce." 475 F Supp $2 d$ at 1347 . Because this construction would not accord well with Morrison, it would raise constitutional questions and therefore the court concluded that RLUIPA does not authorize money damages actions against prison officials in their individual capacities. See id. But see Agrawal III, 2006 US Dist LEXIS 88697 at *8-15, 32-47 (finding damages available against officials in their individual capacities). The Agrawal III court relies extensively on analogy between RLUIPA and its predecessor, RFRA, which courts have held does allow damages against officials in their individual capacities, see, for example, Jama $v$ INS, 343 F Supp 2d 338, 374 (D NJ 2004) (reading "RFRA to allow for individual capacity suits ... against individual defendants"); Mack v O'Leary, $80 \mathrm{~F} 3 \mathrm{~d}$ 1175, 1177 (7th Cir 1996) (holding that a prisoner could sue state officials in their individual capacities), vacd and remd on other grounds as O'Leary $v$ Mack, 522 US 801 (1997). In Mack, "Judge Posner noted that RFRA says nothing about remedies except that a person ... may ... obtain appropriate relief against a government." Agrawal III, 2006 US Dist LEXIS 88697 at *38, quoting Mack, 80 F3d at 1177 (omissions in original) (quotation marks omitted).

153 See Daker I, 2006 US Dist LEXIS 94593 at *30-31. 
damages from officials acting in their individual capacities remains an unsettled question.

Again, almost no cases brought under RLUIPA include allegations of physical harm. ${ }^{154}$ Nominal damages are a longstanding remedy for violations of rights that do not result in any harm - they "are an appropriate means of vindicating rights whose deprivation has not caused actual, provable injury."155 While nominal damages are an appropriate remedy where no "real" harm has been done, they may not be where the harm is more substantial-for instance, where a prisoner is repeatedly punished for refusing to eat a certain diet or comply with a grooming policy. ${ }^{156}$ Many courts agree that nominal damages are available to vindicate RLUIPA rights."

Punitive damages should be available for RLUIPA claims. ${ }^{158}$ "[P]unitive damages are never awarded as a matter of right; the finder of fact, after reviewing the entire record, is called upon to make a 'moral judgment' that the unlawful conduct warrants such an award to punish the wrongdoer and deter others." ${ }^{\text {"19 }}$ Presumably, prisoners would have a high bar to meet in order to convince the finder of fact that the wrongdoer - the State in some form-should be punished for its treatment of the plaintiff - a criminal. Yet, "prisoners do not lose their right to practice their religion when the prison gate closes behind

154 Two cases where severe weight loss was considered physical harm are Pratt $v$ Corrections Corporation of America, 124 Fed Appx 465, 467 (8th Cir 2005) (holding that sufficient physical injury had been alleged to allow plaintiff to proceed with claims for damages), and Wolff $v$ New Hampshire Department of Corrections, 2007 WL 586687, *4-5 (D NH) (allowing a RLUIPA claim for a prisoner who lost forty-nine pounds living on bread and water for a year after being denied a kosher diet). For another example of physical harm, see Boles, 402 F Supp $2 \mathrm{~d}$ at 1246 (permitting a plaintiff to bring a claim for compensatory damages for mental anguish and emotional distress resulting from an eye injury).

Some courts acknowledge injuries that are not easily categorized. See, for example, Meyer $v$ Teslik, 411 F Supp 2d 983, 989 (WD Wis 2006) (noting that being banned from "engaging in a specific religious practice [and deprived] of the opportunity to participate in the only group worship services offered during a three month period is no de minimis deprivation"); Wolfe v Ferguson, 2005 US Dist LEXIS 40978, *78 (WD Ark) (finding that denying access to feathers infringed plaintiff's constitutional rights, and therefore also his statutory rights under RLUIPA).

155 Kyle v Patterson, 196 F3d 695, 697 (7th Cir 1999).

156 See, for example, Warsoldier, 418 F3d at 995-96 (recounting "a series of punishments" aimed at forcing compliance).

157 See, for example, Royal v Kautzky, 375 F3d 720, 722-25 (8th Cir 2004) (holding that nominal and punitive damages are available under $\$ 1997 \mathrm{e}(\mathrm{e})$ ); Thompson $v$ Carter, 284 F3d 411, 418 (2d Cir 2002) (same); Searles v Van Bebber, 251 F3d 869, 878-81 (10th Cir 2001) (same).

158 But compare the cases cited in note 157 with Jordan v Miami-Dade County, 439 F Supp 2d 1237,1242 (SD Fla 2006) (holding that only nominal, not punitive, damages are available under $\S 1997 \mathrm{e}$ (e) without an allegation of physical injury); Williams $v$ Lyon, 2006 WL 1207725, *4 (D $\mathrm{Vt}$ ) (denying punitive damages because the injury was inflicted without evil intent or reckless indifference to constitutional rights).

159 Shidler, 446 F Supp 2d at 946-4\%, yii ' .ing Kyle, 196 F3d at 697. 
them." ${ }^{160}$ When a prison official takes an action that wantonly infringes upon a prisoner's right to freely exercise religion, punitive damages have been found particularly appropriate. ${ }^{161}$

\section{Parallel Claims and Avoiding ABSURdity}

Any solution to the confusion about RLUIPA relief must account for the purpose of RLUIPA (to protect the free exercise of prisoners), the purpose of PLRA (to reduce frivolous litigation by prisoners), and the purpose of compensatory damages (to compensate for actual injury). The solution proposed here considers the problem of collapsing parallel First Amendment and RLUIPA claims and how that endangers the protection Congress envisioned. Regardless of any collapsing of claims, RLUIPA cases face the challenge of PLRA's physical injury requirement. A careful analysis of the consequences attendant on imposing a physical injury requirement before allowing any remedies shows that such a requirement would make RLUIPA a null statute for prisoners. ${ }^{162}$ If RLUIPA parallels a constitutional right in statute form, however, courts may be able to follow pre-Smith precedent for awarding compensatory damages.

\section{A. RLUIPA and First Amendment Claims}

As stated above, most RLUIPA claims do not include allegations of physical harm. ${ }^{163}$ Instead, they mimic First Amendment claims where the damage is the denial of a right and the loss incurred, not harm to the physical person. Because the RLUIPA standard is stricter-that is, the least restrictive means to protect a compelling government interest instead of neutral laws (or policies) of general applicability-the conduct violating RLUIPA covers more territory than conduct violating the First Amendment. But the domains of violations are similar, and the fundamental right-the free exercise of religion-is identical even though one is statutory and one is constitutional.

For prisoners, "RLUIPA provides additional protection for religious worship, respecting that Smith set only a constitutional floornot a ceiling - for the protection of personal liberty." determining what is appropriate relief is to look at what relief is avail-

160 Moskowitz, 432 F Supp at 948, citing Cruz v Beto, 405 US 319 (1972).

161 See, for example, Arroyo Lopez v Nuttall, 25 F Supp 2d 407, 410 (SDNY 1998) (awarding $\$ 5,000$ in punitive damages to a prisoner who was shoved to the ground while he was praying).

162 The land use provisions of RLUIPA are not affected by PLRA.

163 See Part IV.B, especially note 154.

164 This claim is particularly strong because of the background of RLUIPA, while it might be weaker for statutes with a more tenuous connection to a constitutional right.

165 Mayweathers $v$ Newland, 314 F3d 1062, 1070 (9th Cir 2002). 
able for violations of First Amendment rights. If First Amendment rights are the floor, damages for RLUIPA violations should at least match, if not exceed, damages for First Amendment violations.

But damages are not analyzed until after a violation has been established. Because establishing a violation depends on the differing standards for RLUIPA and the First Amendment, it is crucial to evaluate the claims separately. Sometimes courts improperly conflate claims, using the standard set forth in Smith to evaluate RLUIPA claims. ${ }^{166}$ What is particularly unfortunate about such an error in process is that it directly undercuts the very purpose of RLUIPA. Congress made the effort not once, but twice, to pass a statute reinstating what it viewed as core First Amendment values. Furthermore, when the first statute (RFRA) was struck down and Congress narrowed the scope for RLUIPA, it deliberately chose to protect the group of people most vulnerable to government pressure and most susceptible to harm: prisoners. By conflating RLUIPA and First Amendment claims when analyzing possible violations, courts deny prisoners the stronger protection of their statutory rights when the prisoners fail to meet the higher bar for establishing a violation of their constitutional rights.

\section{B. RLUIPA and PLRA}

RLUIPA specifically states that it is not to be "construed to amend or repeal the Prison Litigation Reform Act of 1995." ${ }^{167}$ Although it passed PLRA in order to cut down on prisoner litigation, the cases Congress sought to prohibit were not those making serious constitutional claims but those that were entirely frivolous. ${ }^{168}$ Claims that are only for mental and emotional distress unconnected to an actual injury (loss) are not eligible for monetary damages. Nominal or punitive damages may, of course, be appropriate, as described above.

166 See, for example, Edelkind v Neustrom, 2006 US Dist LEXIS 52407, *28-29 (WD La). Edelkind's RLUIPA and First Amendment claims were conflated and both evaluated under the standard of mere reasonableness, rather than RLUIPA's requirement of a compelling governmental interest and a showing that the interest is accomplished by the least restrictive means. A recent First Circuit case confirmed that courts must seriously evaluate whether or not the policy meets the least restrictive means requirement. In a stinging opinion, the court of appeals admonished the district judge that deference to prison officials does not mean a rubber stamp for their policies. See Spratt v Rhode Island Department of Corrections, 2007 US App LEXIS 8021, *19 (1st Cir).

16742 USC $\$ 2000 \mathrm{cc}-2(\mathrm{e})$.

168 See 141 Cong Rec S7524 (May 25, 1995) (statement of Sen Dole) ("Prisoners have filed lawsuits claiming such grievances as ... being served creamy peanut butter instead of the chunky variety they had ordered."). For an analysis of the congressional intent behind RLUIPA, see generally Anh Nguyen, Comment, The Fight for Creamy Peanut Butter: Why Examining Congressional Intent May Rectify the Problems of the Prison Litigation Reform Act, $36 \mathrm{Sw}$ U L Rev 145 (2007) (proposing two interactive interpretations of PLRA's physical injury requirement). 
What was recoverable as compensatory damages for First Amendment violations pre-Smith remained recoverable after it - until PLRA was passed. The physical injury requirement is what altered the damages available. Smith changed the difficulty of proving a deprivation of free exercise rights, and PLRA made it nearly impossible to get damages when these rights were violated, according to the way most courts have interpreted it. So when RLUIPA came along, a mere statute instead of the actual First Amendment, it did not make much headway for getting damages.

RLUIPA states that "[a] person may assert a violation of this [Act] as a claim or defense in a judicial proceeding and obtain appropriate. relief against a government. ${ }^{169}$ When the distress is caused by a violation that once would have been considered a deprivation of a First Amendment (constitutional) right and is now a deprivation of an RLUIPA (statutory) right, appropriate relief may entail compensatory damages. RLUIPA is acting in the stead of the First Amendment, according to Congress's intent; therefore, violations of RLUIPA ought to be treated as if they were constitutional violations. As the Supreme Court stated in Stachura, damages cannot be awarded for abstract rights - such as the right to freely exercise one's religion-but they can be awarded for specific losses-such as the loss of worship services or sacred objects.

So two situations are possible. First, the deprivation of the right of free exercise causes an actual injury of some kind, which the court can identify and evaluate. Second, the deprivation of the right of free exercise is identifiable but does not seem to cause any actual injury. In the first situation, the injury is likely to be a lost opportunity. ${ }^{170}$ Courts, accustomed to calculating the value of intangible losses (such as consortium) are well-equipped to determine the value of, for instance, denial of religious services over a period of months, or the forced shearing of a prisoner's hair. ${ }^{171}$ If a court decides that an actual injury occurred-as the courts did for the voting rights cases alluded to in Stachura - then it should be able to compensate for that actual injury. Because an actual injury could well cause mental and emotional distress, it is appropriate for courts to take that distress into consideration when determining compensation for the injury. In the second

16942 USC § $2000 \mathrm{cc}-2(a)$.

170 RLUIPA cases almost invariably involve some sort of loss, often of proper diet, desired services, or access to paraphernalia.

171 Courts have determined the value of such losses. See, for example, Arroyo Lopez $v$ Nuttall, 25 F Supp 2d 407, 410 (SDNY 1998) (awarding $\$ 2,000$ in compensatory damages and $\$ 5,000$ in punitive damages when a prisoner was shoved during prayer). See also Jackson $v$ Verdini, 2005 Mass Super LEXIS 279, $* 4$ n 1 (mentioning a previous settlement of one such claim for $\$ 20,000$ ). 
situation, where no actual injury is determined, compensatory damages are probably not available; and because there is no actual loss, any mental or emotional distress triggered by the deprivation are, in theory, compensable with nominal damages."

If RLUIPA is interpreted to be tightly constrained by PLRA's physical injury requirement, prisoners would have no recourse when they suffer a one-time deprivation of their right or a deprivation the prison subsequently amends. They would not be eligible for injunctive relief where they cannot show likelihood of recurrence. They cannot claim punitive damages (where the circuit would allow them) if they cannot show actual malice. They would have no recompense at all for the violation.

Thus, PLRA would make RLUIPA's text inoperative for all but ongoing, persistent violations of free exercise rights, and, perhaps, violations caused by clear malice and therefore eligible for punitive damages. Prisoners would lack a remedy under RLUIPA even though the violation of their rights was established and even where it comes close to shocking the conscience, as when a prisoner, whose religious beliefs prevent him from cutting his hair, is forcibly restrained and shaved by fellow inmates. ${ }^{173}$ In other words, applying the PLRA physical injury requirement instead of the traditional rule's actual injury requirement renders Congress's Act a nullity.

Although PLRA's physical injury requirement has the potential to fatally undercut the protective purpose of RLUIPA, allowing RLUIPA claims to win compensatory damages for actual - though not physical-injury would not undercut PLRA's purpose of inhibiting frivolous litigation. It may be important to bear in mind that while prisoners sometimes demand millions, ${ }^{174}$ courts are more sensible about appropriate damages. ${ }^{175}$ Cases where prisoners endure depriva-

172 In unusual situations, where the violation is caused by egregious behavior, a court might award punitive damages as well. The Supreme Court, however, has recently insisted that punitive damages be tied to compensatory damages in some rational proportion. The implications of such a rule are unclear for cases where only nominal instead of compensatory damages are awarded. See State Farm Mutual Automobile Insurance Co v Campbell, 538 US 408, 429 (2003).

173 See Clark v Briley, 2005 US Dist LEXIS 21350, *4 (ND III).

174 See, for example, Bloch v Samuels, 2006 US Dist LEXIS 53732, *6 (SD Tex) (demanding an aggregate of over $\$ 30$ million in damages); Edelkind, 2006 US Dist LEXIS 52407 at $* 2$ (demanding \$11 million); Spavone v City of New York, 420 F Supp 2d 236, 238 (SDNY 2005) (demanding about $\$ 700,000$ ). But see Smith, 401 F Supp 2d at 1242 (seeking $\$ 500$ from each defendant). Few cases mention the amounts sought, but indications are that prisoners are not always realistic about what their injuries are worth.

175 Many cases may settle once a court determines that a violation has occurred; very few cases are available showing damages awarded to prisoners for violations of their First Amendment rights. For an example of highly specific damage calculations, see Lowrance $v$ Coughlin, 862 F Supp 1090, 1120 (SDNY 1994) (awarding compensatory damages (\$132,000) and punitive damages $(\$ 25,000)$ to a prisoner who had been punitively transferred). 
tions of their free exercise rights that merit large damages are extremely few and far between. Therefore, courts should heed RLUIPA's mandate of appropriate relief by applying the traditional tort law of compensation damages, PLRA's physical injury requirement notwithstanding.

In this way the prisoner will receive no more and no less than proper recompense for the loss stemming from his violated right: he is compensated neither for the abstract value of the right itself nor his mental and emotional distress alone. But to read PLRA to bar all compensatory damages would be to make RLUIPA a meaningless gesture against Smith's incursion on First Amendment rights. Even if PLRA is read to bar claims under RLUIPA for mental and emotional distress, it should not bar claims for compensatory damages for the loss of free exercise rights.

\section{CONCLUSION}

RLUIPA was drafted to ensure that no government or government actor shall "impose a substantial burden on the religious exercise" of prisoners. ${ }^{176}$ Claims under the statute entitled to appropriate relief should be compensated as a constitutional tort would be. While that would often mean no more than nominal damages in compensation, it does leave open the door for punitive damages when prison officials act in malicious ways. And where the prisoner's loss is a provable-though not physical-injury that a court can measure, such as the loss of hair or access to worship services, courts are competent to grant compensation damages for that loss.

Finally, although many plaintiffs lose their RLUIPA cases, or do not win monetary awards, they have been winning a changed system. One court warned that its dismissal of claims "should not be construed as a license to ignore future religious accommodation requests from inmates with individualized religious beliefs." ${ }^{17}$ The court made its expectations clear: "Defendants will take the religious accommodation requests seriously and document their efforts to find the least restrictive means to protect the compelling interests at stake in a correctional setting." ${ }^{178}$ Prisons have adapted to provide more flexible meal programs, a wider array of religious services, and in some circumstances are showing more toleration for religious items. If Congress's intent was to protect the free exercise of religion by statute as

17642 USC $\$ 2000 \mathrm{cc}-1$ (a).

177 Smith v Beauclair, 2006 US Dist LEXIS 56561, *37 (D Idaho).

178 Id. 
it was once protected by the First Amendment, it may have succeeded in spite of the uncertainty it created in the law.

179 RLUIPA cases allege violations of a variety of religions including not only Islam, Judaism, and Roman Catholicism, but also Hinduism, Buddhism, Odinism, Wicca, and even atheism. The only claim possibly brought by a Protestant Christian was Granguillhome v Utah Board of Pardons, 2006 US Dist LEXIS 88996, *5 (D Utah) (alleging preferential treatment by the Pardon Board for members of The Church of Jesus Christ of Latter-day Saints). Whether or not Congress considered Wiccans and Buddhists when it passed RLUIPA, the protections the statute affords are faithful to the original goals of the First Amendment: to preserve the right to freely exercise one's religion, whatever it may be. 


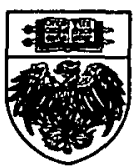

